http://dx.doi.org/10.12775/szhf.2013.051

\author{
STEPAN IVANYK
}

\title{
Czy Kazimierz Twardowski wpłynął na historiografię ukraińskiej filozofii?
}

\section{Historia ukraińskiej filozofii Hilarego Święcickiego}

Za jedną z chronologicznie pierwszych prób napisania historii ukraińskiej filozofii można uznać pracę Начала философіи въ русской литературы XI-XVI вв. [Początki filozofii w literaturze ruskiej ${ }^{1}$ XI-XVI w.], która ukazała się drukiem we Lwowie w $1901 \mathrm{roku}^{2}$. Autor tej pracy - Hilary Święcicki (1876-1956) - to znany ukraiński filolog, etnolog, muzeoznawca i działacz społeczno-kulturalny. Od 1905 do 1952 roku był on dyrektorem Muzeum Cerkiewnego we Lwowie, od 1913 - docentem prywatnym (a od 1941 - profesorem) literatur wschodnio- i południowosłowiańskich na Uniwersytecie Lwowskim, od 1914 - członkiem Towarzystwa Naukowego im. T. Szewczenki we Lwowie, a od 1945 - przewodniczącym Wydziału Językoznawstwa Instytutu Nauk Społecznych Akademii Nauk USRS we Lwowie. Święcicki pozostawił po sobie olbrzymią spuściznę naukową, głównie z dziedziny historii sztuki i muzeoznawstwa, był również autorem Słownika ukraińsko-polskiego (Lwów, 1920). Spod jego pióra wyszło jednak też kilka prac filozoficznych,

\footnotetext{
${ }^{1}$ Słowa „ruski”, „Rusin” używane w Galicji do pierwszych dziesięcioleci XX wieku, faktycznie są odpowiednikami współczesnych „ukraiński”, „Ukrainiec”.

${ }^{2}$ I. Svěncickìj, Načala filosofii v" russkoj Literaturě XI-XVI vv., L'vov" 1901.
} 
wśród których szczególne znaczenie ma wspomniane studium historyczno-filozoficzne.

W Początkach filozofii... Święcicki rozpatruje dwa przeciwstawne stanowiska w historiografii filozofii ruskiej, które wychodzą z następujących założeń:

(A) Początki filozofii ruskiej zbiegają się z początkami literatury ruskiej w ogóle (X wiek n.e.); za pierwszych przedstawicieli filozofii ruskiej należy uważać pisarzy ruskich, w których utworach są zawarte wątki metafizyczne. Główni przedstawiciele tego nurtu to Gawriił Archimandryta i Maria Biezobrazowa.

(B) Początki filozofii ruskiej to dopiero wiek XVIII-XIX, kiedy do Imperium Rosyjskiego docierają idee filozoficzne z Europy Zachodniej (chodzi głównie o Wolffa, Kanta i Hegla); za pierwszych przedstawicieli filozofii ruskiej należy uważać pierwszych adeptów filozofii zachodniej w Imperium Rosyjskim. Główni przedstawiciele tego stanowiska to Wasilij Kluczewskij i Klemens Hankiewicz.

Oba te stanowiska według Święcickiego są nieadekwatne. Stanowisko (A) opiera się na zbyt szerokim rozumieniu pojęcia filozofii (obejmującym wszelką literaturę traktującą o kwestiach metafizycznych i teologicznych), natomiast stanowisko (B) - na zbyt wąskim (obejmującym wyłącznie teoretyczną spekulację na wzór zachodnich systemów filozoficznych). Nieuzasadnione jest zarówno dopatrywanie się teorii filozoficznych w literackich utworach pisarzy staroruskich, jak i całkowite negowanie istnienia jakiejkolwiek myśli filozoficznej na Rusi do XVIII wieku. Należy więc szukać „złotego środka”.

Autor stawia sobie za cel - na podstawie analizy materiału źródłowego do dziejów literatury ruskiej XI-XVI w. - wskazać zawierające się w nim idee filozoficzne, a następnie „odkryć ich organiczny związek i konsekwencję” ${ }^{3}$. Wyniki przeprowadzonej analizy dały Święcickiemu podstawę do dokonania periodyzacji historii filozofii ruskiej. Mianowicie okres od XI do XVI w. dzieli Święcicki na dwie części:

(1) okres „rusko-bizantyjski”: XI-XIV w. (od Nestora Kronikarza do metropolity Cypriana);

(2) okres "greko-scholastyczny”: XV-XVI w. (od Sorskiego do Oteńskiego).

Cechami charakterystycznymi filozofii ruskiej w okresie rusko-bizantyjskim są:

${ }^{3}$ Tamże, s. 2. 
(a) wpływ bizantyjskiej tradycji filozoficznej: filozofia ruska tego okresu ma charakter przeważnie kompilacyjny - podstawowe pojęcia filozoficzne są przejęte prawie w niezmienionej formie przez autorów ruskich z gotowych wzorców filozofii bizantyjskiej (wschodniopatrystycznej);

(b) eklektyzm (brak ideowego związku wewnętrznego): istnienie wspólnego podłoża wszystkich idei filozoficznych autorów ruskich tego okresu (filozofia wschodniopatrystyczna) nie pociągnęło za sobą powstania własnej tradycji filozoficznej: każdy z autorów ruskich wykładał swoje poglądy bez uwzględnienia (a może nawet nie wiedząc o istnieniu) poglądów innych autorów ruskich; dlatego też w tym okresie na Rusi „filozofia jako nauka, sama w sobie, nie istniała i żadnego systemu nie utworzyła".

(c) południowo-zachodnia lokalizacja geograficzna: w okresie tym ośrodki ruskiej myśli filozoficznej są w zdecydowanej większości skoncentrowane w „południowo-zachodniej Rusi” (tj. na Rusi Kijowskiej, czyli późniejszej Ukrainie).

Do cech charakterystycznych filozofii ruskiej w okresie greko-scholastycznym należą z kolei:

(a) wpływ scholastycznej tradycji filozoficznej: przejęcie charakterystycznego dla niej sposobu filozofowania, który polega na rozumowym rozbiorze zagadnień filozoficznych zawartych w Piśmie Świętym;

(b) ideowy związek wewnętrzny: zaczynając od Nila Sorskiego i kończąc na Zenowiju Oteńskim, filozofowie ruscy stawiali sobie jedno zadanie - krytyczną analizę kwestii teologicznych - i posługiwali się przy tym tą samą metodą „scholastyczną": rekonstrukcją tych kwestii w formie sylogizmów; stąd można mówić o istnieniu w tym okresie pierwszych systemów (psychologiczna teoria Sorskiego) i pierwszej szkoły filozoficznej („scholastycznej”);

(c) północno-wschodnia lokalizacja geograficzna: w tym okresie ośrodki ruskiej myśli filozoficznej są w zdecydowanej większości skoncentrowane w „północno-wschodniej Rusi” (tj. na Rusi Moskiewskiej, czyli w późniejszej Rosji).

Za wspólną cechę filozofii ruskiej w obu okresach Święcicki uważa jej skoncentrowanie się na problematyce etycznej. W okresie XI-XIV w. wykrystalizowało się według Święcickiego etyczne zabarwienie ruskiej myśli filozoficznej: ruskie kompilacje wzorców bizantyjskich były podporządkowane

\footnotetext{
${ }^{4}$ Tamże, s. 10.
} 
konkretnym celom praktycznym i politycznym, cechowały się wyraźną selektywnością; poszukiwano głównie odpowiedzi na pytania „Po co żyć? i „Jak żyć?"; skupiano się przede wszystkim na pojęciach etycznych (dobra i zła, szczęścia, grzechu, odpowiedzialności etc.). Etyczny charakter filozofii ruskiej utrzymał się także w okresie XV-XVI w.; zmieniła się tylko forma ujęcia podstawowych pojęć i motywów (zamiast kompilacji - krytyczna analiza).

Święcicki dopatruje się też pewnych prawidłowości w historii filozofii na Rusi, które to prawidłowości opiera on na "geografii” wyodrębnionych okresów. Według Święcickiego - rozwój filozofii na Rusi da się przedstawić jako dzieje regularnego przepływu idei filozoficznych między dwoma jej «biegunami» geograficznymi: południowo-zachodnim i północno-wschodnim. Okres pierwszy - to początek myśli filozoficznej na Rusi południowo-zachodniej z centrum w Kijowie, któremu towarzyszył prawie całkowity brak idei filozoficznych na Rusi północno-wschodniej (z centrum w Moskwie). W okresie drugim role tych ośrodków odwróciły się: mamy prawie całkowitą stagnację intelektualną na Rusi południowo-zachodniej i szybki rozwój myśli filozoficznej na Rusi północno-wschodniej (nawiązujący do tradycji kijowskiej). Święcicki zauważa, że pod koniec drugiego okresu można zaobserwować pierwsze objawy ponownej „zamiany ról”: pod wpływem ucznia Maksyma Greka, księcia Andrieja Kurbskiego książę Konstanty Ostrogski w 1576 roku założył w Ostrogu Akademię na wzór kolegium jezuickiego. Od założenia wspomnianej Akademii zaczyna się ponowne odrodzenie myśli filozoficznej na Ukrainie, podczas gdy na Rusi Moskiewskiej pod koniec XVI wieku dochodzi do prawie całkowitego jej zaniku. Święcicki proponuje w związku z tym zastosować opisany wyżej schemat do periodyzacji okresów rozwoju filozofii ruskiej również po XVI wieku, a mianowicie wyodrębnić:

(3) w XVII-XVIII w. - okres „ukraiński” (związany z działalnością naukową Ostrogskiej i Kijowskiej Akademii Duchowej);

(4) w końcu XVIII i na początku XX w. - okres „rosyjski” (związany z przeszczepieniem na grunt rosyjski idei francuskich encyklopedystów i niemieckich systematyków). 


\section{Koncepcja „historiografii filozofii” Kazimierza Twardowskiego}

Swoje poglądy na temat historii filozofii Kazimierz Twardowski wyłożył w artykule Franciszek Brentano a historia filozofii $(1895)^{5}$. Powołując się na klasyfikację Maurycego Straszewskiego, Twardowski wyodrębnił trzy metody uprawiania historii filozofii:

(1) metodę biograficzną, która polega na przedstawianiu dziejów filozofii jako historii twórców idei filozoficznych;

(2) metodę krytyczno-sprawozdawczą, która polega przedstawianiu dziejów filozofii jako historii poszczególnych idei i systemów filozoficznych;

(3) metodę konstrukcyjną, która polega na ujawnianiu w dziejach filozofii praw rządzących jej rozwojem.

Są przy tym dwa rodzaje metody konstrukcyjnej:

(a) aprioryczna metoda konstrukcyjna, porządkująca dzieje filozofii według z góry przyjętej zasady;

(b) aposterioryczna metoda konstrukcyjna, „wydobywająca” prawa rozwoju filozofii z samych faktów historycznych.

Rozumie się - pisze Twardowski - że metoda konstrukcyjna jest najwyższym szczeblem dziejopisarstwa filozoficznego i że jedynie ona prowadzi nas do zrozumienia dziejowego postępu, objawiającego się w naukach filozoficznych ${ }^{6}$.

Z dwóch rodzajów metody konstrukcyjnej Twardowski oddaje pierwszeństwo metodzie aposteriorycznej jako prawdziwie naukowej, ponieważ jest ona pozbawiona istotnej wady metody apriorycznej, a mianowicie - tendencji do deformacji faktów w celu ich dostosowania do z góry przyjętych zasad rozwoju filozofii.

Aposterioryczna metoda konstrukcyjna jest najmłodsza i zarazem najtrudniejsza ze wszystkich: udanych przykładów jej zastosowania jest niewiele. Za wzorzec takiego sposobu uprawiania historii filozofii dzieła Twardowski uznaje Die vier Phasen der Philosophie und ihr augenblicklicher Stand [Cztery fazy filozofii i jej stan obecny] (1895) swojego mistrza - Franza Brentana. Brentano wysunął w tej pracy hipotezę o powtarzaniu się w dziejach filozofii czterech faz - dwóch faz rozkwitu i następnych dwóch faz upadku.

${ }^{5}$ K. Twardowski, Franciszek Brentano a historia filozofii, Przełom I, nr 11 (z 3 sierpnia 1885), s. 335-346, przedruk w: tenże, Rozprawy i artykuły filozoficzne, Lwów 1927, s. 229-242.

${ }^{6} \mathrm{~K}$. Twardowski, Franciszek Brentano a historia filozofii, [w:] tenże, Rozprawy i artykuly filozoficzne. 
Opierając się na tej hipotezie historiozoficznej, Brentano przeprowadził oryginalną periodyzację historii filozofii (na cztery okresy, z których każdy miał wspomniane wyżej cztery fazy) i określił jej współczesny stan jako początek pierwszej fazy nowego (piątego z kolei) okresu.

Podsumowując - według Twardowskiego, rzetelna historia filozofii, uprawiana za pomocą metody aposteriorycznej i zarazem konstrukcyjnej, to „filozofia historii filozofii” lub „historiozofia filozofii”, a jej zadaniem jest wskazanie ogólnego prawa, wedle którego przebiega historyczny rozwój filozofii, będący podstawą periodyzacji tego rozwoju

\section{Kazimierz Twardowski i historia ukraińskiej filozofii Hilarego Święcickiego}

Przyszedł czas odpowiedzieć sobie na pytanie, jaki stosunek ma opisana w rozdziale 1. niniejszego artykułu historia ukraińskiej filozofii Święcickiego do opisanej w rozdziale 2. koncepcji „historiografii filozofii” Twardowskiego. $\mathrm{Z}$ pozoru - żaden. Jednak bliższa historyczna i merytoryczna analiza dowodzi tezy przeciwnej.

Źródła dokumentalne świadczą o tym, że Twardowski i Święcicki znali się i łączyły ich stosunki koleżeńskie. Nazwisko Święcickiego figuruje wśród czterdziestu zaproszonych przez Twardowskiego na wieczorne zebranie towarzyskie w hotelu "George" we Lwowie, które odbyło się 11 stycznia 1931 roku z okazji wręczenia mistrzowi pamiątkowego medalu od byłych uczniów w związku z jego odejściem na emeryturę ${ }^{8}$. Pod datą 23 sierpnia 1934 roku Twardowski zapisał z kolei w swoim dzienniku:

Dowiedziałem się dzisiaj o nowym kwiatku naszego administracyjnego bałaganu. Docent nasz Święcicki, który wniósł podanie o paszport ulgowy i zasi-

\footnotetext{
${ }^{7}$ W środowisku Szkoły Lwowsko-Warszawskiej do poglądów Twardowskiego na metodologię historiografii filozoficznej nawiązywali w swoich pracach Władysław Tatarkiewicz (np. „O pisaniu historii filozofii” (1952)) i Stefan Swieżawski (np. „Zagadnienie historii filozofii” (1966)). Wydaje się, że zwłaszcza faworyzowanie przez Twardowskiego metody konstrukcyjnej nie pozostało bez wpływu na zaproponowaną przez Tatarkiewicza koncepcję „scalania faktów” w dziejopisarstwie filozoficznym oraz na przeprowadzoną przez Swieżawskiego krytykę metody „biograficznej”, metody „systematycznej” i „kronikarstwa faktograficznego” wraz z uzasadnieniem potrzeby konstruowania „filozoficznej historiografii filozofii” mającej na celu ustalenie pewnego „teleologizmu” w dziejach filozofii.

${ }^{8}$ K. Twardowski, Dzienniki, cz. II: 1928-1936, Warszawa-Toruń 1997, s. 186.
} 
łek, chcąc się udać na jakiś tam zjazd zagraniczny ${ }^{9}$, otrzymał wprawdzie zasiłek w kwocie 600 zł, ale dotąd nie otrzymał pozwolenia na wydanie paszportu ulgowego. Ciekaw jestem, czy to ono przyjdzie jeszcze na czas! $!^{10}$

Kiedy jednak doszło do nawiązania znajomości Święcickiego z Twardowskim? Stało się to w 1895 roku, kiedy Twardowski przybywszy z Wiednia do Lwowa objął katedrę filozofii miejscowego uniwersytetu, a Święcicki, po ukończeniu gimnazjum lwowskiego, właśnie rozpoczął studia na Wydziale Filozofii tejże uczelni. Na Uniwersytecie Lwowskim Święcicki słuchał wykładów Twardowskiego i nawiązał z przyszłym Mistrzem Szkoły Lwowsko-Warszawskiej osobiste kontakty. Po ukończeniu studiów w 1899 roku, prawdopodobnie właśnie dzięki poparciu Twardowskiego, Święcicki dostał roczne stypendium do Uniwersytetu w Sankt-Petersburgu, gdzie opracowywał materiały Cesarskiej Biblioteki Publicznej. Jak wynika z korespondencji Święcickiego z Twardowskim z tego okresu, ukraiński stypendysta zbierał w Petersburgu materiały do rozprawy doktorskiej na temat historii filozofii na Rusi, której promotorem miał być Twardowski. Tak oto w liście z 12 grudnia 1899 roku Święcicki pisze do Twardowskiego:

Wielce Szanowny Panie Profesorze! Od trzech miesięcy przebywam w Petersburgu, gdzie uczęszczam do archeologicznego instytutu, zamierzając w przyszłości starać się o miejsce archiwarza i bibliotekarza w jednej z ruskich bibliotek w Galicji.

Ponieważ zajęcia w instytucie zabierają mi tylko wieczorne godziny, poświęcam więc cały dzień dalszym studiom historyczno-filozoficznym w akademicznej [sic!] i publicznej bibliotece, według cennych wskazówek Pana Profesora, dawanych mi w uniwersytecie. Dawniejsza znajomość literatury ojczystej zrodziła we mnie myśl, a teraźniejsze głębsze wniknięcie w stare pamiętniki ruskiego piśmiennictwa ukształtowało ją w plan: podać historię filozofii na Rusi od XI do XVIII wieku włącznie. Zebrane materiały pozwalają mi już teraz przedstawić w przybliżeniu dyspozycję zamierzonej pracy: ośrodki filozoficznej myśli na Rusi; wpływy greckie i zachodniopolskie; samoistna filozoficzna myśl. Źródłowe studia w tym kierunku spodziewam się ukończyć w Petersburgu do połowy marca, a następnie uzupełnić je w Kijowie i Warszawie do Wielkanocy - tak że z początkiem letniego kursu będę mógł przyjechać do Lwowa z uporządkowanym materiałem. Dzieląc się z Wielce Szanownym Panem Profesorem wiadomością o rodzaju i kierunku moich zajęć, śmiem zapytać się, czy podobna

\footnotetext{
9 Święcicki w 1934 brał udział w Zjeździe Filologów Słowiańskich w Pradze.

${ }^{10}$ K. Twardowski, Dzienniki, cz. II: 1928-1936, s. 358.
} 
praca może być przyjęta jako dysertacja i prosić Pana Profesora o dalsze cenne rady i względy ${ }^{11}$.

\section{Z kolei w liście z 26 grudnia 1899 roku czytamy:}

Zasyłając wyrazy najserdeczniejszej wdzięczności za tak łaskawą odpowiedź, śpieszę przedłożyć Wielce Szanownemu Panu Profesorowi materiał, którym obecnie rozporządzam i posługuję się [...]. W następujący zaś sposób śledzę za rozwojem filozoficznej myśli u odnośnego autora: zestawiwszy ogólny obraz jego poglądów dociekam źródła, z którego pochodzą - mając go staram się zbadać ich konsekwentność, wpływ na ogół i związek z dalszym rozwojem. Będę bardzo szczęśliwy i wdzięczny Wielce Szanownemu Panu Profesorowi za cenne wskazówki dotyczące przedłożonego materiału i planu ${ }^{12}$.

Do obrony doktoratu u Twardowskiego jednak nie doszło, najprawdopodobniej dlatego, że niedługo po powrocie do Lwowa Święcicki w 1900 roku został powołany do rocznej służby wojskowej w armii austriackiej, w tym samym czasie zaostrzyły się też stosunki polsko-ukraińskie we Lwowie i Galicji Wschodniej ${ }^{13}$. Niemniej jednak, nie ma wątpliwości co do tego, że rozpatrzona przez nas praca „Początki filozofii...” Święcickiego w istocie rzeczy jest publikacją jego zamierzonej pracy doktorskiej, przygotowywanej pod kierunkiem Twardowskiego.

Z korespondencji Święcickiego i Twardowskiego też wynika, że Początki filozofii... były pisane wedle bezpośrednich metodologicznych wskazówek założyciela Szkoły Lwowsko-Warszawskiej ${ }^{14}$. Forma i treść tej pracy wyraźnie dowodzą, że uwagi Twardowskiego mogły polegać właśnie na zasugerowaniu zastosowania do rekonstrukcji historii filozofii Rusi aposteriorycznej metody konstrukcyjnej. Głównym celem Początków filozofii... Święcickiego jest bo-

\footnotetext{
${ }^{11}$ Archiwum Kazimierza Twardowskiego w Uniwersytecie Warszawskim, sygn. 02-1-37, s. $13-15$.

12 Tamże, s. 16-17.

${ }^{13}$ Ostatecznie Święcicki obronił pracę doktorską pt. „Maksim der Grieche” [„Maksym Grek”] w 1902 roku na Uniwersytecie Wiedeńskim u slawisty Vatroslava Jagicia (Zob. rozprawę doktorską Święcickiego w Archiwum Uniwersytetu Wiedeńskiego, Pn. 1523, Fol. 8).

${ }^{14} \mathrm{O}$ tym, że Święcicki interesował się poglądami filozoficznymi Twardowskiego świadczy również fakt, że w prywatnej bibliotece Święcickiego, która szczęśliwie zachowała się do dziś, znajdują się liczne pisma Twardowskiego, np. „Wyobrażenia i pojęcia”, „O metodzie psychologii: przyczynek do metodologii porównawczej badań naukowych”, „O filozofii średniowiecznej”, „Mowy i rozprawy”, „Rozprawy i artykuły filozoficzne”.
} 
wiem wykazanie na podstawie opracowanego materiału źródłowego prawa „organicznego związku i konsekwencji” ${ }^{15}$ rozwoju filozofii ruskiej, które to prawo ma być podstawą do przeprowadzenia periodyzacji tej filozofii ${ }^{16}$. Według Święcickiego takim prawem jest powtarzanie się naprzemiennych faz podstawowych:

(a) rozkwit filozofii na Rusi południowo-zachodniej i upadek filozofii na Rusi północno-wschodniej;

(b) rozkwit filozofii na Rusi północno-wschodniej i upadek filozofii na Rusi południowo-zachodniej.

Dokonana przez Święcickiego periodyzacja rozwoju filozofii na Rusi prezentuje się pod tym względem - jak pamiętamy - w sposób następujący:

(1) XI-XIV w. - faza (a);

(2) XV-XVI w. - faza (b);

(3) XVII-XVIII w. - faza (a);

(4) koniec XVIII w. - początek XX w.- faza (b).

W ten sposób dochodzimy do wniosku, że Początki filozofii $w$ literaturze ruskiej XI-XVI w. Święcickiego można uważać za udaną i oryginalną egzemplifikację na gruncie ukraińskim postulowanej przez Twardowskiego w odniesieniu do historii filozofii aposteriorycznej metody konstrukcyjnej. $\mathrm{Na}$ postawione w tytule artykułu pytanie należy więc odpowiedzieć twierdząco.

\section{Bibliografia}

I. Svěncickij, Načala filosofii v" russkoj Literaturě XI-XVI vv., L'vov" 1901.

Swieżawski S., Zagadnienie historii filozofii, Warszawa 1966.

Twardowski K., Dzienniki, cz. II: 1928-1936, Warszawa-Toruń 1997.

Twardowski K., Rozprawy i artykuły filozoficzne, Lwów 1927.

${ }^{15}$ I. Svěncickì, Načala filosofii v" russkoj Literaturě XI-XVI vv., L'vov" 1901, s. 2.

${ }^{16}$ Warto zauważyć, że jest to swego rodzaju antycypacja sprecyzowanego w Szkole Lwowsko-Warszawskiej przez W. Tatarkiewicza programu historii filozofii, uwzględniającej nie tylko filozofię explicite, lecz także filozofię implicite. 


\begin{abstract}
The paper is aimed to prove that the work of the Ukrainian philosopher Hilary Święcicki The origins of philosophy in Ruthenian literature of XI-XVI century (Lviv, 1901) was written under the influence of the founder of the Lvov-Warsaw School of philosophy Kazimierz Twardowski. Results of the analysis indicate that this influence was of the methodological nature and it manifested itself in the use by Swięcicki aposteriori constructive method, developed by master of Twardowdki - Franz Brentano.
\end{abstract}

Key words: Biographical method, critical-reporting method, a priori constructive method, a posteriori constructive method 